\title{
The Development of Hierarchy of Effects Model in Advertising
}

\author{
Bambang Sukma Wijaya \\ Universitas Bakrie, Jakarta
}

\section{ARTICLE INFO}

Received: August 27, 2011

Final revision: February 5, 2012

Keywords:

AISDALSLove,

AIDA,

Hierarchy of Effects,

Advertising,

Consumer Audience.

\section{A B S T R A C T}

This paper aims to review the hierarchy of effects models in advertising, especially the well-known model, AIDA (Attention, Interest, Desire, and Action). Since its introduction by Lewis (1900) and generally attributed in the marketing and advertising literature by Strong (1925), the concept of AIDA's hierarchy of effects model has been used by many researchers, both academicians and practitioners. The model is used to measure the effect of an advertisement. However, the development of information technology has radically changed the way of how people communicate and socialize; as well as a paradigm shift from product-oriented marketing to consumer-oriented marketing or people-oriented marketing. Therefore, the variables in the hierarchy of effects model needs to be updated in respond to the latest developments in the notice of public power as consumer audience. Based on deep literature review and reflective method, this paper introduces a new developed concept of hierarchy of effects model that was adopted from AIDA's hierarchy of effects model, namely: AISDALSLove (Attention, Interest, Search, Desire, Action, Like/dislike, Share, and Love/ hate).

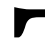

$\mathrm{T}$ The advertising world today has grown very rapidly, not only from the creative side, but also from strategy and media technology. A lot of interesting advertisings were born not only from unexpected creative concept, but was also executed with advanced final touch or crafting. Similarly with the power of strategy which is not as simple as before, for which to inform and persuade people to buy the product. Now, advertising is also used for a more meaningful purpose, which is building the brand and attaching values, either tangible or intangible so that the consumers become loyal and even love or have a sense of belonging to the brand.

The development of creative and strategic concepts of communication is supported by the development of vastly growing media, marked with the advent 
of new media and alternative media which have a surprisingly creative breath, such as ambient media, happening art, guerilla media, creative publicity, branded entertainment, and so on. The form is also more varied and converged in such a way, thus it becomes so difficult to find a standalone media in delivering the messages of a product.

The stated phenomenon raises question about the true definition of advertising. Some people say advertising is simply way to sell a product -to announce what products are available, who made them, and where you go to buy (Moriarty et al., 2009: 53).

Meanwhile, a modern definition of advertising includes other important factors, such as media, audience, and goals. Moriarty et al defined advertising is a paid form of persuasive communication that uses mass and interactive media to reach broad audiences in order to connect an identified sponsor with buyers (a targe audience) and provide information about product (goods, service, and ideas). This definition has five basic factors: is usually paid by the advertiser, the sponsor is identified, generally reaches a broad audience of potential consumers, seeks to inform and also persuade or influence consumers, and the message is conveyed through many different kinds of mass media and also now interactive types of media.

Fairly similar to the definition above, Lane et al. (2011: 41) stated that advertising is a message paid for by an identified sponsor and usually delivered through some medium of mass communication. The fundamental principle of good advertising is that it must be built around the overall marketing plan and execute the communication elements of a more far-reaching marketing program. While Egan (2007: 19) defined advertising is a non-personal form of mass communication with a high degree of control over design and placement but potentially a low degree of persuasion and credibility. It is never either neutral or unbiased.

In the communication philosophy perspective, advertising principally is a communication that sells. So any form of communication that sells something, or delivers sales messages, then can be defined as advertising. By looking at various strategic developments, which sometimes advertising is no longer just a communication tool to "sell something", but more extensive than that which creates "meaning towards something" followed by attaching to a brand and becomes an integral part of people's lives, then advertising now can be defined as communication that creates perception (Wijaya,

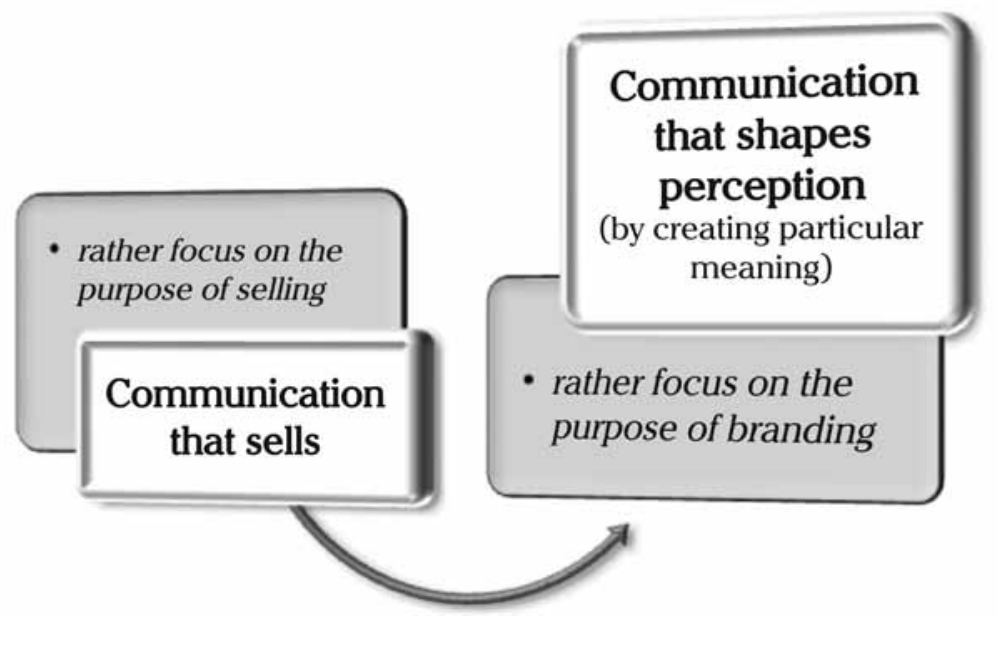

Figure 1. Redefinition of advertising in the communication perspective

(Source: Wijaya, 2011)
2011). Hence whatever the form or communication activities that are directed to create perceptions or certain meanings toward something (product, person, institution, etc.), then it can be defined as advertising.

In short, modern advertising is strategic communication that aims to accomplish something-to create impact, by which we mean a certain consumer response, such as understanding information or persuading someone to do something (Moriarty et al., 2009: 55). To achieve that consumer response, an advertising strategy is driven by objectives (statements of desired consumer response), and these objectives can be measured to determine whether the advertising was effective.

Likewise with the function of advertising that continues to evolve in the same direction with the development of human civilization. If at the beginning of its development, the information function primarily to inform the existence of a product, then when the presence of similar products gave birth to competition so that the persuasion function becomes important, which followed by entertainment function, currently the education function and social inspiration function have become no less important (Wijaya, 2011). Lane et al. (2011:43) noted that advertising could be viewed from two related perspectives: (1) its economic role and (2) its social and cultural role in communicating not only product information but also social values.

The education function was born to reduce the strength of persuasion function that is used by some of industrial players with 'all sorts of ways' which gave birth of cynicism to the presence of advertising. The education function has also strengthened the role of advertising communication in shaping positive things and is attached to a brand.

Whilst the function of social inspiration has a broader role, in which advertising also helps to promote the values of kindness and humanity, with the intention that people get inspired and motivated to perform good deeds which have broad impact to the communities where the person lives. Unde the current level of scrutiny, advertisers must be aware of both economic and social aspects of thei advertising. The majority of both practitioners an consumers accept the fact that advertising has an ethical and moral responsibility to provide product information that is truthful and socially appropriate. In marketing perspective, this phenomenon wa mentioned by Kotler as a shift of marketing trend from product-oriented to consumer-oriented after that to human spirit (Kotler et al., 2010).

\begin{tabular}{|c|c|c|c|c|c|}
\hline FUNCTION $\rightarrow$ & Information & Persuasion & Entertainment & Education & $\begin{array}{c}\text { Social } \\
\text { Inspiration }\end{array}$ \\
\hline $\begin{array}{l}\text { Consumer } \\
\text { Insights }\end{array}$ & $\begin{array}{l}\text { "What's new?" } \\
\text { "Any product that } \\
\text { I need?" }\end{array}$ & $\begin{array}{l}\text { "Which one is the } \\
\text { best for me?" } \\
\text { "Any product that } \\
\text { understands me?" }\end{array}$ & $\begin{array}{l}\text { "Ads are so } \\
\text { boring" }\end{array}$ & $\begin{array}{l}\text { "I hate ads! Just } \\
\text { cheating, selling, } \\
\text { no caring" }\end{array}$ & $\begin{array}{l}\text { "Ads only } \\
\text { hypnotize me } \\
\text { to waste my } \\
\text { money!" }\end{array}$ \\
\hline Focus on & $\begin{array}{l}\text { Functional } \\
\text { Benefits }\end{array}$ & $\begin{array}{l}\text { Functional, } \\
\text { Emotional \& } \\
\text { Symbolic Benefits }\end{array}$ & $\begin{array}{l}\text { Emotional \& } \\
\text { Symbolic Benefits }\end{array}$ & $\begin{array}{l}\text { Functional \& } \\
\text { Social Benefit }\end{array}$ & $\begin{array}{l}\text { Symbolic, } \\
\text { Emotional \& } \\
\text { Social Benefit }\end{array}$ \\
\hline Creative Strategy & $\begin{array}{l}\text { Informational, } \\
\text { Announcement }\end{array}$ & $\begin{array}{l}\text { Head on, } \\
\text { life style, } \\
\text { comparative ads }\end{array}$ & $\begin{array}{l}\text { Humor, dramatic, } \\
\text { musicals }\end{array}$ & $\begin{array}{l}\text { 'How-to' ads, } \\
\text { advertorials }\end{array}$ & $\begin{array}{l}\text { Brand Social } \\
\text { Responsibility }\end{array}$ \\
\hline
\end{tabular}

Figure 2. Development of the advertising function (Source: Wijaya, 2011) 
Viewing the function, role and impact of advertising is so enormous to people's lives, therefore it is also interesting to recognize the effect of advertising to the individual lives, both as communication target audience and consumer that become marketing target of a brand. Individual responses to advertising are usually mediated or filtered by factors such as motivation and ability to process information, which can radically alter or change the individual's response to advertising (Vakratsas and Ambler, 1999 43). Likewise, advertising affects consumers' daily lives, informing them about products and services and influencing their attitudes, beliefs, and ultimately their purchases (McDaniel et al., 2011: 556).

Though advertising cannot change consumers' deeply rooted values and attitudes, it may succeed in transforming a person's negative attitude toward a product into a positive one. For instance, serious or dramatic advertisings are more effective at changing consumers' negative attitudes. Humorous ads, on the other hand, have been shown to be more effective at shaping attitudes when consumers already have a positive image of the advertised brand (Solomon, 2011).

Advertising can also affect the way consumers rank a brand's attributes, such as color, taste, smell, and texture. Advertising's role, therefore, is to make consumers, whatever their current state of attitudes toward, information about, or image of a brand, more informed about the brand and more generally favorable to it. Advertising must, that is, produce some sort of mental change in the consumer: he or she must think differently about the brand after being exposed to successful advertising (Weilbacher, 2001).

Meanwhile, some hierarchy of effect models have been developed and used by researchers from both academician as well as marketing communication practitioners in a bid to measure the communication effect of an ad to the consumer audience behavior. These models are also used as preparation basis of marketing communication strategy.
Proponents of the traditional hierarchy framework suggest that audiences respond to messages in a very ordered way that is firstly cognitively (thinking), then affectively (feeling) and thirdly conatively (doing). Cognition is typically defined as 'mental activity' as reflected in knowledge, beliefs or thoughts that someone has about some aspect of their world (Barry and Howard, 1990). While the affective component is any degree of feeling and emotion, in a general sense, which can be attributed to the brand and conation refers to either intension to perform a behavior (e.g. purchase) or the behavior itself (Egan, 2007: 43)

One of the earliest attempts to model the effect of advertising was the AIDA model generally attributed to Strong in 1925 but which actually originated with E. St. Elmo Lewis around 20 to 30 years earlier. The model was designed to represent the stages through which a salesperson should take a prospect but was later adopted as a basic framework to explain how persuasive communication (mainly advertising) worked. AIDA stands for Attention, Interest, Desire and Action.

Similar popular model included DAGMAR (Defining Advertising Goals for Measuring Advertising Results) which was Colley's (1961) suggested formula for setting communications orientated objectives. DAGMAR incorporated elements of Awareness, Comprehension, Conviction and Purchase as stages of the influence of advertising message on consumer behavior. Awareness is the stage where advertising can raise audience awareness on advertising message (similar to Attention and Interest in AIDA). Comprehension is the stage where consumer audience understands the core message of an ad, after that Conviction is a stage where audience believes the genuineness of the message that is delivered through advertising (similar to Desire in AIDA, since a strong conviction can raise a desire to purchase), and Purchase is where the consumer audience follow up his belief in the advertising message through an act of purchase (this stage is similar to Action in AIDA).
Lavidge and Steiner (1961) and Wells et al. (1965) were also trying to represent the communication process in their hierarchy models as shown below. Lavidge and Steiner believed that advertising was an investment in a long-term process that moved consumers over time through a variety of stair-step stages, beginning with product 'unawareness' and moving ultimately to actual purchase (Barry \& Howard, 1990: 99). Therefore, they added the stages of 'knowledge', 'liking' and 'preference' prior 'conviction'. While Wells et al. further highlight the importance of the process of 'perception' before reaching the stage of 'understanding' and 'persuasion' (Egan, 2007: 44).

There are still actually many hierarchies of effects models developed by academicians, researchers and practitioners since its inception over a century ago. Some are as shown in the table below (Barry \& Howard, 1990: 100-102).

Why do we need to know about the sequential hierarchy of effects in advertising? One reason is that determining hierarchical processes allows us to predict behavior (Preston \& Thorson, 1983; Barry \& Howard, 1990). Yet, the easiest way to predict what someone will do is simply to ask them what they intend to do (i.e., the intention-behavior-relationship). A second reason is that understanding the hierarchy of effects provides information on what advertising strategy to emphasize. A third reason is that the hierarchy of effects has proven valuable for helping to organize planning, training, and conceptual tasks within a firm (Barry \& Howard, 1990: 108).

\section{METHODS}

This paper is a conceptual paper. The objective of this paper is to review and analyze the hierarchy of effects models in advertising and introducing a new concept of hierarchy of effects model that developed from the well-known model, AIDA (Attention, Interest, Desire and Action). In formulating the concept, the author performed literature review and then reflected or dialogued it with the latest phenomenon, which is the change in the ways of people communicate and socialize as a result of the development of information technology marked by the rise of social media. Besides, development of advertising media and marketing communication strategy also affects and are affected by consume audience behavior towards advertised brands, so that the previous hierarchy of effects model need to be updated according to the latest developments in the notice of public power.

\section{RESULTS AND DISCUSSION}

What is most evidently missing from the previou models is the post-purchase effect. That is the effect

\begin{tabular}{|c|c|c|c|c|c|}
\hline & \multicolumn{2}{|c|}{ KNOWLEDGES } & \multicolumn{2}{|c|}{ FEELING } & $\begin{array}{c}\text { MOTIVATION } \\
\rightarrow \text { ACTION } \\
\end{array}$ \\
\hline AIDA (Strong '25) & Attention & Inte & rest & Desire & \\
\hline DAGMAR Colley ‘61 & Awareness & \multicolumn{3}{|c|}{ Comprehension Conviction } & Purchase \\
\hline Lavidge \& Steiner ‘61 & Awareness & Knowle & & $\begin{array}{r}\text { Convi } \\
\text { Preference }\end{array}$ & Purchase \\
\hline \multirow[t]{2}{*}{ Wells et al. '65 } & $\begin{array}{r}\text { Awa } \\
\text { Perceptiol }\end{array}$ & & \multicolumn{2}{|c|}{ Understanding } & Persuasion \\
\hline & COGNIT & & & FFECTIVE & CONATIVE \\
\hline
\end{tabular}

Figure 3. Hierarchy of effects models (Source: Egan, 2007) 
Table 1. A summary of popular hierarchy models (Source: Barry and Howard, 1990)

\begin{tabular}{|c|c|c|c|}
\hline Year & Model & Developer & Comment \\
\hline 1898 & $\begin{array}{l}\text { AID: Attention, Interest, } \\
\text { Desire }\end{array}$ & E. St Elmo Lewis & $\begin{array}{l}\text { Developed as a sales guide for salesmen to be successful in } \\
\text { moving a prospect to buy. }\end{array}$ \\
\hline \multirow[t]{2}{*}{$\begin{array}{l}\text { Circa } \\
1900\end{array}$} & & & \\
\hline & $\begin{array}{l}\text { AIDA: Attention, } \\
\text { Interest, Desire, Action* }\end{array}$ & E. St Elmo Lewis & $\begin{array}{l}\text { Added the action stage as necessary to convince salesmen } \\
\text { to move buyer prospects through complete selling process. }\end{array}$ \\
\hline 1910 & $\begin{array}{l}\text { AICA: Attention, } \\
\text { Interest, Conviction, }\end{array}$ & Printers Ink Editorial & $\begin{array}{l}\text { The first mention of the hierarchy model for advertising use; a } \\
\text { complete advertisement Action }\end{array}$ \\
\hline 1911 & $\begin{array}{l}\text { AIDAS: Attention, } \\
\text { Interest, Desire, Action, } \\
\text { Satisfaction }\end{array}$ & Arthur F. Sheldon & $\begin{array}{l}\text { Added 'permanent satisfaction' as a necessary part of the per- } \\
\text { suasive and long-run selling process: this final stage not car- } \\
\text { ried through to contemporary literature. }\end{array}$ \\
\hline 1915 & $\begin{array}{l}\text { AICCA: Attention, } \\
\text { IIterest, Confidence, } \\
\text { Conviction, Action }\end{array}$ & Samuel R . Hall & $\begin{array}{l}\text { The necessary steps in writing a good, persuasive advertise- } \\
\text { ment. }\end{array}$ \\
\hline 1921 & $\begin{array}{l}\text { AIDCA: Attention, } \\
\text { Interest, Desire, } \\
\text { Caution, Action }\end{array}$ & Robert E. Ramsay & $\begin{array}{l}\text { Mentioned this model at the beginning of his book on how } \\
\text { to write effective direct advertising although the model is not } \\
\text { developed in the book. }\end{array}$ \\
\hline 1921 & $\begin{array}{l}\text { AIDCA: Attention, } \\
\text { Interest, Desire, } \\
\text { Conviction, Action }\end{array}$ & Harry D. Kitson & $\begin{array}{l}\text { Used this model in writing about how the mind of the buyer } \\
\text { works. }\end{array}$ \\
\hline 1922 & $\begin{array}{l}\text { AlJA: Attention, Interest, } \\
\text { Judgment, Action }\end{array}$ & Alexander Osborn & Writing about the creative /persuasive process in advertising. \\
\hline 1940 & $\begin{array}{l}\text { AIDCA: Attention, } \\
\text { Interest, Desire, } \\
\text { Conviction, Action }\end{array}$ & Clyde Bedell & $\begin{array}{l}r \text { advertising to sell it, it must follow these 'proved selling } \\
\text { atagems' as formulated by Kitson in } 1921 \text {. }\end{array}$ \\
\hline 1956 & $\begin{array}{l}\text { AIDMA: Attention, } \\
\text { Interest, Desire, } \\
\text { Memory, Action }\end{array}$ & Merrill Devoe & $\begin{array}{l}\text { Referred to the importance of different psychological se- } \\
\text { quences in constructing advertisements (AIDCA and AIDMA) } \\
\text { but does not develop these in his book. }\end{array}$ \\
\hline 1961 & $\begin{array}{l}\text { ACCA :Awareness, } \\
\text { Comprehension., } \\
\text { Conviction, Action }\end{array}$ & Russell H. Colley & $\begin{array}{l}\text { Proposed this model as important to the development of } \\
\text { specified advertising goals and measuring advertising effec- } \\
\text { tiveness. }\end{array}$ \\
\hline 1961 & $\begin{array}{l}\text { EPCCA: Exposure, } \\
\text { Perception, } \\
\text { Communication } \\
\text { (Knowledge), } \\
\text { Communication } \\
\text { (Attitude), Action }\end{array}$ & $\begin{array}{l}\text { Advertising Research } \\
\text { Foundation }\end{array}$ & $\begin{array}{l}\text { The model supported by the foundation of advertising practi- }- \text { tioners and researchers to be used for developing more effec- } \\
\text { tive advertising campaigns. }\end{array}$ \\
\hline 1962 & $\begin{array}{l}\text { AAPIS: Awareness, } \\
\text { Acceptance, } \\
\text { Preference, Intention, } \\
\text { Sale, } \\
\text { Provocation }\end{array}$ & $\begin{array}{l}\text { Harry D. Wolfe } \\
\text { James K. Brown } \\
\text { C. Clark Thompson }\end{array}$ & $\begin{array}{l}\text { strated how business used the hierarchy concept as a } \\
\text { ideline to develop advertising strategy }\end{array}$ \\
\hline 1962 & $\begin{array}{l}\text { AlETA: Awareness, } \\
\text { Interest, Evaluation, } \\
\text { Trial, Adoption }\end{array}$ & Everett M. Rogers & $\begin{array}{l}\text { posed the first application of a hierarchy-type model to the } \\
\text { cess of new product adoption. }\end{array}$ \\
\hline 1969 & $\begin{array}{l}\text { PACYRB: Presentation, } \\
\text { Attention, } \\
\text { Comprehension, } \\
\text { Yielding, Retention, } \\
\text { Behavior }\end{array}$ & William J. McGuire & $\begin{array}{l}\text { The first to suggest that probabilities could be associated with } \\
\text { the stages of the hierarchy models to show ultimate behav- } \\
\text { ioral impact of advertising. }\end{array}$ \\
\hline 1971 & $\begin{array}{l}\text { ACALTA: Awareness, } \\
\text { Comprehension, } \\
\text { Attitude, Legitimation, } \\
\text { Trial, Adoption }\end{array}$ & Thomas S. Robertson & $\begin{array}{l}\text { Expanded on the adoption hierarchy of Rogers, this model } \\
\text { more based on Howard and Sheth buyer behavior model (at- } \\
\text { tention, comprehension, attitude, intention, purchase). }\end{array}$ \\
\hline 1982 & The Association model & Ivan L. Preston & nsive hierarchy model that pre- \\
\hline 1983 & and the expanded & & 'er- \\
\hline 1984 & Association model & Esther Thorson & $\begin{array}{l}\text { tising awareness, advertising elements awareness, associa- } \\
\text { tion evaluation, product perception, integrated perception, } \\
\text { products evaluation, prior evaluation. integrated evaluation, } \\
\text { product stimulation, prior stimulation, integrated stimulation, } \\
\text { search, search perception, search evaluation, search simula- } \\
\text { tion, trial, trial perception, trial stimulation, adoption, adop- } \\
\text { tion perception, adoption evaluation, adoption stimulation. }\end{array}$ \\
\hline
\end{tabular}

" Italics indicate change in stage/nomenclature from previous model(s). on future decision making and brand relationship having experienced consumption. Evidently a good consumption experience is likely to lead to other purchase or long good perception and feeling toward the brand (Egan, 2007: 44). As early as 1911, Sheldon included 'permanent satisfaction' as the final step in the Lewis/Strong model to create AIDAS (Attention, Interest, Desire, Action and Satisfaction). Rogers (1983) as part of his theory of adoption suggested that there were various stages including knowledge, persuasion, decision (adopt/ reject), implementation and confirmation (continued adoption, discontinuance, continued rejection). Bovee et al. (1995) took this further by suggesting that the post-purchase period is the point when advertising (and the other marketing communication tools) should be used to bolster the customers' sense of satisfaction about the action or purchase and that this phase represents the beginning of a new cycle in the communication process.

Development of hierarchy of effect model by incorporating post-purchase stage can be seen in the figure 4.

In spite of the enthusiasm with which the marketing community has embraced the hierarchy-of-advertising-effects explanation of how advertising works, there is still no specific evidence that the consumer research measurements implied by the specifics of the model like brand awareness, brand feature

\begin{tabular}{|c|c|c|c|c|}
\hline & KNOWLEDGES & FEELING & $\begin{array}{l}\text { MOTIVATION } \\
\rightarrow \quad \text { ACTION }\end{array}$ & POST PURCHASE \\
\hline AIDA(S) & Attention & Desire & Action & (Satisfaction) \\
\hline Rogers & \multicolumn{2}{|r|}{ Persuasion } & $\begin{array}{l}\text { Decision } \\
\text { Implementation }\end{array}$ & Confirmation \\
\hline \multirow[t]{2}{*}{ Bovee et al. } & \multicolumn{2}{|c|}{$\begin{array}{c}\text { Awareness Acceptance } \\
\text { Comprehension Preference }\end{array}$} & Ownership & Reinforcement \\
\hline & COGNITIVE & AFFECTIVE & CONATIVE & CONATIVE \\
\hline
\end{tabular}

Figure 4. Extended hierarchy of effects models (Source: Egan, 2007) awareness, brand preference, and intention-to-buy specific brands actually do reflect the way that advertising works or its specific effects in moving consumers toward purchase action (Weilbacher 2001). After all, there is no evidence that every hierarchy of advertising effects ends in a sale.

While Egan (2007: 46) noted a number of shortcomings of classical hierarchy models:

- There is no empirical support that suggest consumers actually go through each stage

- Hierarchy models do not take account of the potential for interaction between stages

- Post-purchase experience is often not considered

In addition, the existing hierarchy of effect mode is not completely accommodate the phenomenon of today's information technology that gave birth to many new social media that change the way people communicate, socialize, and influence consume audience behavior. It is not an exaggeration to state that the internet is the most revolutionary new medium to be developed since television in the late 1940s and '50s. Internet has made its greates impact on society as a personal communication medium and a business-to-business sales medium (Cappo, 2003: 193).

Development of a broader advertising role as a conmunication device and brand development also 
became writer's consideration. Therefore writer developed AIDA's hierarchy of effects model by adding several relevant elements, such as $\mathrm{S}$ (Search), L (Like/dislike), S (Share) and Love (Love/hate), which then become AISDALSLove. Regarding the development of hierarchical model, Hall (2002 23) argued that advertisers need to move away from explicit and implicit reliance on hierarchical models of advertising effects and develop models that place affect and experience at the center of the advertising process.

Writer put special attention on concept of AIDA model, considering this model is the most popular, widely used in studies to measure the effect of advertising, as well as inspiring the birth of new hierarchy of effect models (see Table 1). Barry \& Howard (1990: 101) stated that so important was the AIDA formulation at the turn of the century that Strong (1925) estimated that 90 per cent of persons engaged in selling and the vast majority of advertising and selling textbooks fully endorsed the Lewis-Sheldon hierarchical framework.

Apart from variable development in stages by adding 'S' (Search) element, 'L' (Like/dislike), 'S (Share) and 'Love' (Love/hate), in AISDALSLove too, writer carried out grouping of advertising effect to short-term effect and long-term effect, especially related to development of the advertised brand.

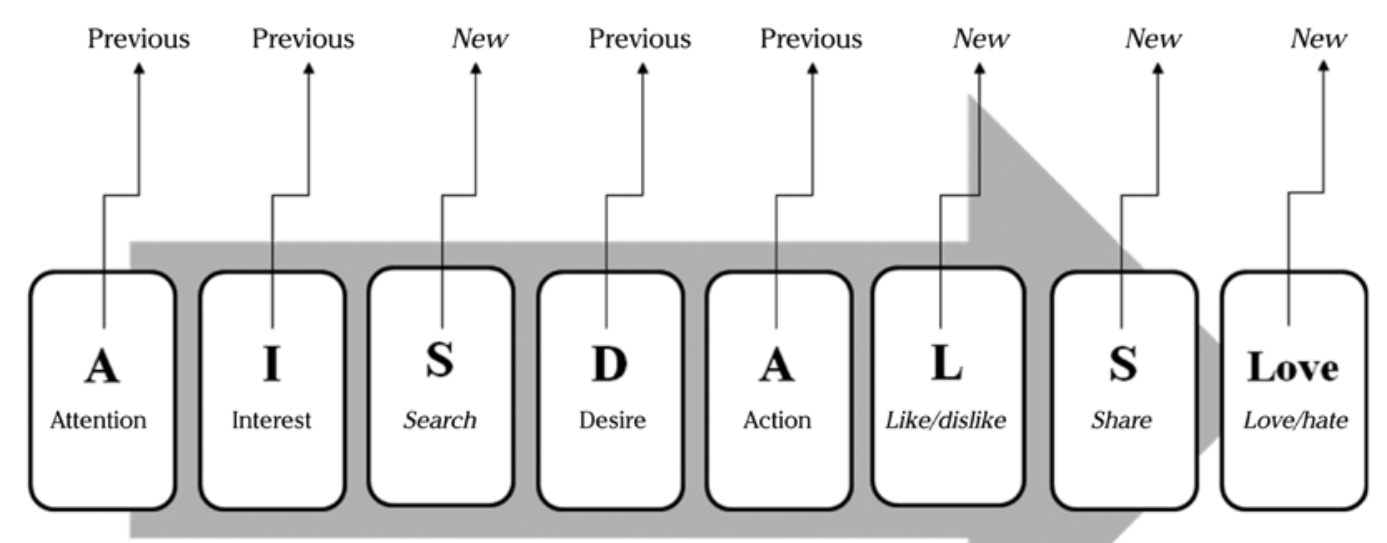

Short - Term Effects of Advertising

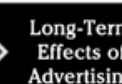

Figure 5. AISDALSLove Model types of information: (1) brands, (2) attributes, (3) evaluations, and (4) experiences (Alba et al., 1991). Recall of brands refers to the set of brands that consumers recall from memory whenever problem recognition has been stimulated, recall of attributes refers to specific facts about a product or service, recall of evaluations refers to our effort to find out overall evaluations or attitudes (that is, our likes and dislikes), because our memory for specific details decays rapidly over time. Evaluations are also more likely to be recalled by consumers who are actively evaluating the brand when they are exposed to relevant information. Meanwhile, recall of experiences refers to internal search by recalling experiences from autobiographical memory in the form of specific images and the effect associated with them (Baumgartner et al., 1992).

Finally, consumers can recall information from memory only if they have the opportunity to do so. Time pressure or distractions will limit internal search. At other times, information may be missing or some uncertainty may surround the recalled information. Then Consumers engage in an external search of outside sources, such as dealers, trusted friends or relatives, published sources (magazines, pamphlets, or books), the internet, other marketing communications tools and media, or the product package. Consumers use external search to collect additional information about which brands are available as well as about the attributes and benefits associated with brands in the consideration set (Hoyer and Macinnis, 2010: 205).

For either pre-purchase or ongoing search, consumers can acquire information from five major categories of external sources: retailer search, media search, interpersonal search, independent search, and experiential search (Beatty \& Smith, 1987).

\section{Like/Dislike (L)}

This element is closely related to consumers' experience after purchasing and using the product because of tempted by the advertisement. If consumers like the product, then consumers usually feel satisfied and afterward do the next action, such as make a repurchase or reordering. Satisfaction is as an attitude-like judgment following a consumption experience (Lovelock and Wirtz, 2011: 74).

The resulting judgment is labeled positive disconfirmation if the product or service is better than expected, negative disconfirmation if it is worse than expected, and simple confirmation if it is a expected (Oliver, 1997; Lovelock \& Wirtz, 2011). In short, consumers evaluate product or service pe formance through their experience by comparing what they expected, imagined, and convicted with what they perceive they received from a particula supplier.

Thus, the unpleasant experience or not in accordance with the promise delivered by the ads will lead to resentment on the products and usually consumer decides not to try it again. The extremely importance of 'Like/ dislike' effect in post-purchase stage has made Sheldon (1919) completed the AIDA's effect stage with 'S', which is 'Satisfaction' Meanwhile Rogers called it as 'Confirmation', and Bovee et al. named it 'Reinforcement'. The consumer's experience may possibly cause the nex snowball effect, which is share the experience to others about the advertised product.

\section{Share (S)}

In an age where the world is becoming increasingly borderless by the late development of information technology, consumers have the power to perform radical actions that may cause impact to the brand image of a product. This is based on like and dislike experience toward the product they have used.

The case of Prita who shared her unpleasant experience to her friends through internet media about Omni hospital services gives lesson about how bis consumer's role is in spreading information about a product or service, especially supported by information technology facility which able to spread the information widely in instance. Though Prita's voice then tried to be shut through the 'iron-hand of law', 
however people's support through Facebook and the movement of coin collection for Prita is a proof that people (consumer) power cannot be neglected (Wijaya, 2009b).

Meanwhile, the law of small numbers in the consumer's decision making process, whereby people expect information obtained from a small sample to be typical of the larger population (Tversky and Kahneman, 1971; Hoyer and Macinnis, 2010) more strengthening the assumption of the role of consumer experience sharing in influencing other consumers. If friends say that a new hand phone by a particular group is really good or that the food at a particular restaurant is terrible, we believe that information, even if most people do not feel that way.

In fact, reliance on small numbers is another reason that word-of-mouth communication can be so powerful. We tend to have confidence that the opinions of friends or relatives are more reflective of the majority than they may actually be.

Moreover with the growing users of digital social media today, make the consumers become freer in

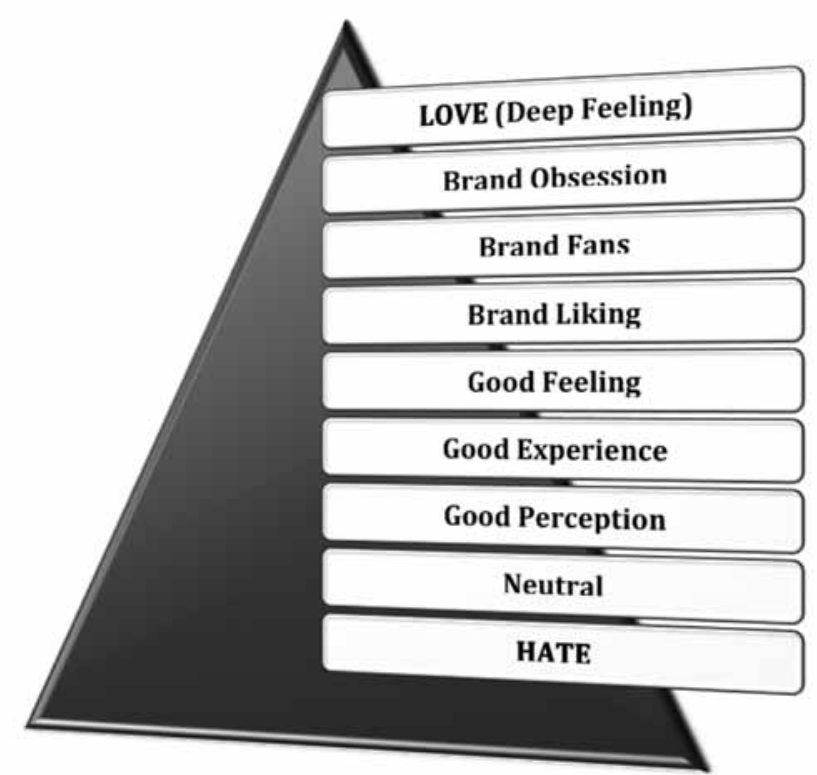

Figure 6. The Pyramid of Love towards Brand (Source: Wijaya, 2011) expressing their experience to the world. Therefore, the key for brands is to empower consumers by delivering an exceptional experience that inspires them to share their stories (Davila, 2011). In recent survey, it's clear that word of mouth via social media, product review sites, etc. where consumer share their experiences is what drives business results.

Apart from the form of storytelling in blogs, consumers also share their experience in the form of letter to the editor in many mass media, updated status in many social media such as Facebook and Twitter, upload video on Youtube, interpersonal rumors in hangout places, product review in certain websites, broadcast messages in messenger facilities and inbox, spamming and hoax, as well as information and comments posting in mailing lists and social media walls.

\section{Love/Hate (Love)}

Long-term effect of an ad is love or hatred of consumers to the advertised brand or product. A consumer, who has already interested to purchase a product after being influenced by the ad's message (visual or verbal), and feel satisfied after a 'simple confirmation' or even 'positive disconfirmation', then share the experience and express his satisfaction towards the products he has been tried, eventually will create a deep feeling to the brand. Some degrees of love towards brand, starts from hate, neutral, good perception, good experience, good feeling, brand liking, brand fans, brand obsession, to deep feeling (love) on the top (Wijaya, 2011: d-13).

A love can also arise due to connection between consumers with story or creative advertising concept. This connection can be presented through indepth understanding of consumers through consumer insight. Supported by a good brand experience, this connection becomes stronger over time so that creates brand loyalty and sense of belonging to the advertised brand. There is no better way to build such a similarly long-lasting brand loyalty than by continually nurturing brand relationship in order to ensure that brand and consumer remain connected (Wijaya, 2009a).

On the contrary, if the consumer experience towards the advertised product has a negative disconfirmation, the consumer will spread rumor to other consumers or society at large with the intention that impact to a bad perception of a product. Instead of love and loyal to a brand, consumer become resentful and may possibly express such hatred in various ways.

That is why advertisers should not focus only on short-term effects of advertising, which raises purchase action, but also consider long-term effect, namely loyalty to the brand which came from good experience on brand and good image about the brand product. As a result, in planning advertising and marketing communication, advertisers should be very careful in presenting 'what to say' and 'how to say' their brand product.

\section{MANAGERIAL IMPLICATIONS}

Many things have changed the face of the ad vertising world today. Besides creativity, strategy development, business landscape changes, and media convergence as well as information technology development also changed the way people communicate which then impact on the change of consumer audience behavior. The increasingly diverse form, be it traditional or modern advertising made advertising needs to be redefined and reinterpreted to answer the challenges of time. Role and function of advertising also continues to evolve from merely inform and persuade people to purchase a product becomes wider to deliver social inspiration to the society.

These developments eventually change our pe spective in viewing advertising effects. The advertising effects are no longer as simple as Attention, Interest, Desire and Action or added with Satisfaction as developed by Strong (1925). This is due to more critical public or potential customers and no longer can be dictated by advertising information. Although the advertisement is quite interesting but it's not enticing enough to create a passion to purchase the advertised product. They tried to look for information before they decide to buy.

Meanwhile, it is no less important after make a purchase is the consumers experience towards the product they buy due to the influence of advertising. This experience can create preference to products so that increase to satisfaction, but conversely can also create aversion which have an impact to consumers' disappointment because what they experience about a product is under their expectation or not in accordance with the communicated promise through advertising. Like/ dislike experience above then caused snow ball effect, that is action to share experience on product/ brand to other consumers, both straight forward through interpersonal communication and through mass media so that has the potential of word-of-mouth. Furthermore with the development of information technology which gave birth to social media sites, the potential of consume 'storytelling' becomes greater. In this case, the role of consumer becomes more powerful in turning on and off a product. 
Lastly, advertising not only has short-term effect on product purchase action, but more than that, advertising also has the effect of building a brand that can be felt in the long run. If advertisers wan the product brand be loved by consumers, then advertisers should have the goodwill to deliver the product message correctly, honest, and came from a good consumer insight so that creates connection between brand and consumers. Advertisers should maintain the consistency of the message and consumer's actual experiences on the benefits of the product, which create consumer confidence and encourage consumer to carry out positive actions that impact positively for the brand. Advertisers should enhance the positive image of products through inspirational communication behaviors, thus strengthening the emotional bond between consumers and brand. Strong bond eventually creates sense of love and sense of belonging to product brand by becoming a loyal consumer, even become brand ambassador voluntarily by promoting the brand they love.

AISDALSLove can help advertisers to measure the effect of advertising they made, can help brand managers or brand owners to understand consumer audience attitude and behavior towards brands, and help them to decide what strategy should be developed at every stage in AISDALSLove.

\section{CONCLUSION}

The hierarchy of effects model AISDALSLove can be described as 'A' for Attention (the stage where consumer audience firstly pay attention to the ad), 'I for Interest (stage at which the consumer audience then become interested in that ad), ' $\mathrm{S}$ ' for Search (the stage where consumer audience will seek for brand, both internally and externally).

'D' for Desire (the stage where consumer audience have a passion towards the brand or product after getting information about the brand or additional information regarding the advertising message), 'A' for Action (stage at which the consumer audience take action in form of purchase of products or the election of a brand to satisfy his/ her desire), ' $L$ ' for Like/ dislike (the stage where after experiencing a product or brand, the consumer audience will like or dislike towards that product).

'S' for Share (this stage is a continuation from the previous stage, in which the consumer audience will express feelings of likes or dislikes by sharing their experience to other consumers directly or through media), and the last is 'Love' for Love/ hate (the stage when after feeling satisfied or not satisfied, and share experiences with others, then will come a deep feeling towards the product or brand as long-term effects, these feelings can be either love or hate)

However, AISDALSLove model is a concept that requires testing through research. Therefore, the authors suggest several studies related to the advertising effects on consumer audience behavior by using the variables that exist in AISDALSLove model, as well as multiple dimensions and indicators in these variables.
Cappo, Joe (2003). The Future of Advertising: New Media, New Clients, New Consumers in the Post-Television Age. USA: McGraw-Hill

Davila, Scott (2012, January 15). Great Customer Experiences Make the Best Brand Stories. Retrieved from http://allthings womma.org/2011/04/28/great-customer-experiences-make-the-best-brand-stories/

Egan, John (2007). Marketing Communications. London: Thomson

Hall, BF. (2002). A New Model for Measuring Advertising Effectiveness. Journal of Advertising Research, 42 (2), 23-31 Hoyer, Wayne D. and Deborah J. Macinnis (2010). Consumer Behavior. Singapore: Cengage

Kotler, Philip, Hermawan Kartajaya \& Iwan Setiawan (2010). Marketing 3.0. Translated by Dian Wulandari. Jakarta: Erlangga Lane, W. Ronald, Karen Whitehill King and Tom Reichert (2011). Kleppner's Advertising Procedure. New Jersey: Pearson Lovelock, Christopher and Jochen Wirtz (2011). Service Marketing: People, Technology, Strategy. New Jersey: Pearson McDaniel, Carl, Charles W. Lamb and Joseph Hair, Jr. (2011). Introduction to Marketing. Singapore: Cengage Moriarty, Sandra, Nancy Mitchell and William Wells (2009). Advertising: Principles \& Practice. New Jersey: Pearson Solomon, Michael R. (2011). Consumer Behavior: Buying, Having, and Being. New Jersey: Pearson

Vakratsas, D \& T. Ambler (1999). How Advertising Works: What Do We Really Know?. Journal of Marketing, 63 (1), 26-43 Weilbacher, William M. (2001). Point of View: Does Advertising Cause a "Hierarchy of Effects"?. Journal of Advertising Research, 41 (6), 19-26

Wijaya, Bantang Sukma (201). New Model of Hierarchy of Effects in Advertising. Proceeding International Seminar on Scientific Issues and Trends, d5-15

(2009, May-June). Brand \& Me. ADOI Magazine

(2009, December 15). Mencermati Balada Prita dan Potret Nestapa Konsumen. Kontan Daily

\section{REFERENCES}

Alba, Joseph W. J. Wesley Hutchinson and John G. Lynch (1991). Memory and Decision Making. In Roberton, Thomas C. and Harold H. Kassarjian (Eds), Handbook of Consumer Behavior. Englewood Cliffs, NJ: Prentice Hall

Barry, Thomas E. \& Daniel J. Howard (1990). A Review and Critique of The Hierarchy of Effects in Advertising. International Journal of Advertising, 9 (2), 98-111
Jorry

Baumgartner, Hans, Mita Sujan and James R. Bettman (1992). Autobiographical Memories, Affect, and Consumer Information Processing. Journal of Consumer Psychology. 1 (1), 53-82 